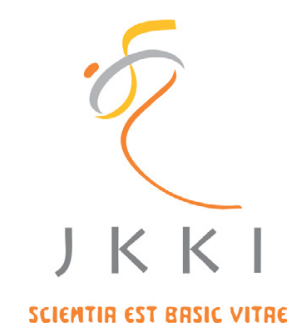

Jurnal Kedokteran dan Kesehatan Indonesia

Indonesian Journal of Medicine and Health

Journal homepage : www.journal.uii.ac.id/index.php/JKKI

\title{
Bacterial isolates and antimicrobial susceptibility in children with acute diarrhea at Ibn Sina Medical College, Bangladesh
}

\author{
Sonia Akter*1, Reena Saad Ferdousi ${ }^{1}$, Mahmuda Siddiqua ${ }^{1}$ \\ ${ }^{1}$ Department of Microbiology, Ibn Sina Medical College, Dhaka, Bangladesh
}

Original Article

\begin{tabular}{l}
\hline \\
\hline ART ICLE INFO \\
\hline Keywords: \\
diarrhea, \\
drug, \\
resistance, \\
antibiotic \\
\hline
\end{tabular}

*Corresponding author: soniaakterkhan83@gmail.com

DOI : 10.20885/JKKI.Vol8.Iss2.art2 History:

Received: November 22, 2016

Accepted: April 13, 2017

Online: June 15, 2017

\section{ABSTRACT}

Backround: Infectious diarrhea is one of common cause of children diarrhea causing mortality and morbidity worldwide. This study was performed to identify the common bacteria and their antimicrobial susceptibility in children with diarrhea.

Methods: A retrospective study was conducted from April 2014 to March 2016 at IBN SINA Medical College Hospital, Bangladesh. Stool samples were cultured on MacConkey agar and blood agar. A standard biochemical procedure was used for full identification of bacterial isolates. Antimicrobial susceptibility tests were done on Mueller-Hinton agar by using disc diffusion method. Data were entered and analyzed by using SPSS version 20 and a $p$-value of $<0.05$ was considered statistically significant.

Results: A total of 186 stool samples were tested for bacterial isolation and $55(29.57 \%)$ cases were found to have bacterial isolates. From the total bacterial isolates, the predominant isolate was E. coli 39 (70.91\%) followed by Salmonella 9 (16.36\%) and Shigella Spp.7 (12.73\%). As much as $84.62 \%$ E. coli were resistant to co-trimoxazole and cefuroxime while $92.31 \%$ E. coli were sensitive to amikacin and $71.79 \%$ were sensitive to cefepime and gentamicin. Salmonella were $100 \%$ sensitive to cefepime, ceftriaxone, cefixime, ceftazidime, and ciprofloxacin. Shigella were $85.71 \%$ sensitive to amikacin and cefepime.

Conclusion: The results show that E. coli were the most frequently isolated pathogen in children. The majority of the bacterial isolates were resistant to multiple antibiotics. Hence, antibiotics susceptibility test is mandatory before prescribing any antibiotics.

Latar Belakang: Diare yang disebabkan oleh infeksi merupakan salah satu penyebab umum diare anak yang menyebabkan mortalitas dan morbiditas di seluruh dunia. Penelitian ini dilakukan untuk mengidentifikasi jenis bakteri dan kerentanan terhadap antimikroba pada anak dengan diare.

Tujuan Penelitian: Studi retrospektif dilakukan dari bulan April 2014 sampai Maret 2016 di IBN SINA Medical College Hospital, Bangladesh. Sampel tinja dikultur pada agar MacConkey dan agar darah. Prosedur biokimia standar yang digunakan untuk mengidentifikasi isolat bakteri. Tes kepekaan terhadap antimikroba dilakukan pada agar Mueller-Hinton dengan menggunakan metode difusi diskus. Data dianalisis dengan menggunakan perangkat lunak uji statistik SPSS versi 20 dan nilai $p<0,05$ dianggap signifikan secara statistik.

Metode: studi retrospektif dilakukan dari bulan April 2014 sampai Maret 2016 di IBN SINA Medical College Hospital, Bangladesh. Sampel tinja dikultur pada agar MacConkey dan agar darah. Prosedur biokimia 
standar yang digunakan untuk mengidentifikasi isolat bakteri. Tes kepekaan terhadap antimikroba dilakukan pada agar Mueller-Hinton dengan menggunakan metode difusi diskus. Data dianalisis dengan menggunakan perangkat lunak uji statistik SPSS versi 20 dan nilai $p<0,05$ dianggap signifikan secara statistik.

Hasil: Sebanyak 186 sampel tinja diuji untuk isolasi bakteri dan sebanyak 55 kasus (29,57\%) ditemukan memiliki isolat bakteri. Dari keseluruhan isolat bakteri, didapatkan bahwa isolat bakteri yang dominan adalah E.coli 39 (70,91\%) diikuti oleh Salmonella 9 (16,36\%) dan Shigella Spp. 7 (12,73\%). Sebanyak 84,62\% E.coli resisten terhadap kotrimoksasol dan cefuroxime sedangkan 92,31\% E.coli sensitif terhadap amikasin dan 71,79\% sensitif terhadap sefepim dan gentamisin. Bakteri Salmonella sensitif terhadap sefepim, ceftriaxone, cifixime, ceftazidime dan ciprofloxacine (100\%). Shigella sensitif terhadap amikasin dan cefepime (85,71\%).

Kesimpulan: Hasil penelitian menunjukkan bahwa E.coli adalah patogen yang paling sering diisolasi pada anak-anak. Sebagian besar isolat bakteri resisten terhadap beberapa antibiotik. Oleh karena itu tes kerentanan terhadap antibiotik wajib dilakukan sebelum meresepkan antibiotik apapun.

\section{INTRODUCTION}

Infective diarrhea is one of the leading causes of morbidity and mortality among children under five years in the developing world and can be caused by a wide range of viruses, bacteria, or parasites. ${ }^{1,2,3}$ The prevalence of the different enteric pathogens varies with the geographical area. $^{2}$ Reports from different parts of the world have implicated various pathogens such as bacteria like; Escherichia coli, Salmonella species, Klebsiella species, Enterobacter species e.t.c. Parasites like; Giardia lamblia, Entamoeba histolytica, and viruses like the Rotavirus with the outbreak of infantile diarrheal disease. ${ }^{4-8}$ Antibiotic resistance is a major global public health concern, particularly in settings where few treatment options are available, either due to lack of availability or affordability of second line therapies. ${ }^{9}$ Commensal Escherichia coli can act as reservoirs of resistance genes in the human gut. These resistant genes might be rapidly transferred to other commensal or pathogenic organisms. ${ }^{10,11}$ Faecal E. coli is regarded as a useful indicator of the spread of acquired antibiotic resistance genes in the community. ${ }^{12,13}$ Due to the overuse of antibiotics and change in epidemiology and antimicrobial resistance of bacterial agents, a study on the local epidemiology of bacterial diarrhea and antimicrobial susceptibility plays an important role in choosing the appropriate antibiotics for empirical treatment. Thus, this study was performed to identify common bacteria and their antimicrobial susceptibility in our region to support choosing a suitable antimicrobial agent.

\section{METHODS}

\section{Study design, participants and data collection}

A retrospective study was conducted from April 2014 to March 2016 at IBN SINA Medical College Hospital, Bangladesh.We reviewed the results of all stool cultures that presented bacterial growth that was taken from children between 0 and 15 years of age from April 2014 to March 2016. Data about patients' sex and age, pathogens isolated and their antimicrobial resistance patterns were taken from the Hospital Microbiology Laboratory unit registration books by using standard data collection format. During that period, 186 patients had their stools cultured and 55 samples presented bacterial growth.

\section{Culture, identification and antimicrobial susceptibility testing}

Stool specimens were collected using wide mouthed sterile plastic containers and transported to the Microbiology laboratory at IBN SINA Medical College Hospital within two hours of collection. Bacterial pathogens E. coli, Salmonella spp and Shigella spp were isolated and identified by conventional methods. ${ }^{14}$ Antimicrobial susceptibility testing was performed by disc diffusion method according to Clinical and Laboratory Standards Institute guidelines (CLSI) on Mueller-Hinton agar (Oxoid, England). ${ }^{15,16}$ Antibiotics tested were amikacin, amoxicillin, clavulanic acid, ciprofloxacin, gentamicin, cefepime, ceftriaxone, 
co-trimoxazole, cefixime, ceftazidime and cefuroxime (Oxoid, England). According to the size of the zones of inhibition, the organisms were classified as sensitive, intermediate or resistant to a specific antibiotic according to CLSI guidelines. ${ }^{15}$ For the purpose of this study, intermediate sensitivity was considered as sensitive.

\section{RESULTS}

During the two-year period, the stools of 186 diarrheal patients aged 0 to 15 years were cultured and $55(29.57 \%)$ samples presented bacterial growth and were included in the study. The characteristic of these patients, 103 were male (55.38\%), while the other 83 were females (44.62\%, Table 1).

Table 1. The result of culture from diarrheal stools in different sex.

\begin{tabular}{llll}
\hline \multirow{2}{*}{ Sex } & \multicolumn{2}{c}{ Culture } & \multicolumn{1}{c}{ Total } \\
& Positive & Negative & \multicolumn{1}{c}{ N(\%) } \\
\hline Female & $20(36.36)$ & $63(48.09)$ & $83(44.62)$ \\
Male & $35(63.64)$ & $68(51.91)$ & $103(55.38)$ \\
Total & $55(100)$ & $131(100)$ & $186(100)$ \\
\hline $\mathrm{X}^{2}=2.16, \mathrm{df}=1, \mathrm{P}=0.142$. &
\end{tabular}

E. coli was the most frequent pathogen, being found in 39 cultures $(70.91 \%$ ), while Salmonella spp. was found in 9 cultures (16.36\%) and Shigella spp. was found in 7 cultures $(12.73 \%)$. The age distribution data revealed that out of 55 culture positive 23 cases (41.82\%) were younger than 4 years, 6 cases $(10.91 \%)$ were between five to nine years and 26 cases ( $47.27 \%$ ) were between ten to fifteen years. E. coli is the most common cause of diarrhea in all age groups (Histogram 1). Among the E. coli, $84.62 \%$ were resistant to cotrimoxazole and cefuroxime. As much as $92.31 \%$ E. coli were sensitive to amikacin and $71.79 \%$ were sensitive to cefepime and gentamicin. Of these, $44.44 \%$ Salmonella were resistance to gentamicin and $100 \%$ Salmonella sensitive to cefepime, ceftriaxone, cefixime, ceftazidime, and ciprofloxacin. As much as $71.43 \%$ Shigella were resistant to amoxiclav, cefixime and gentamicin and $85.71 \%$ were sensitive to amikacin and cefepime (Table 2).

Table 2. Antimicrobial resistance pattern of bacterial isolates from stool samples participants

\begin{tabular}{llcc}
\hline \multicolumn{1}{c}{ Antimicrobial agents } & \multicolumn{2}{c}{ Resistant pattern of bacterial isolates (R \%) } \\
& $\begin{array}{c}\text { E.coli } \\
\text { n (\%) }\end{array}$ & $\begin{array}{c}\text { Salmonella } \\
\text { n (\%) }\end{array}$ & $\begin{array}{c}\text { Shigella } \\
\text { n (\%) }\end{array}$ \\
\hline Amikacin & $3(7.69)$ & $1(11.11)$ & $1(14.29)$ \\
Amoxyclav & $19(48.72)$ & $2(22.22)$ & $5(71.43)$ \\
Cefepime & $11(28.21)$ & $0(0)$ & $1(14.28)$ \\
Ceftriaxone & $27(69.23)$ & $0(0)$ & $2(28.57)$ \\
Cifixime & $28(71.79)$ & $0(0)$ & $5(71.43)$ \\
Ceftazidime & $31(79.49)$ & $0(0)$ & $3(42.86)$ \\
Co-trimoxazole & $33(84.62)$ & $1(11.11)$ & $3(42.86)$ \\
Cefuroxime & $33(84.62)$ & $1(11.11)$ & $4(57.14)$ \\
Ciprofloxacine & $20(51.28)$ & $0(0)$ & $2(28.57)$ \\
Gentamycin & $11(28.21)$ & $4(44.44)$ & $5(71.43)$ \\
\hline
\end{tabular}



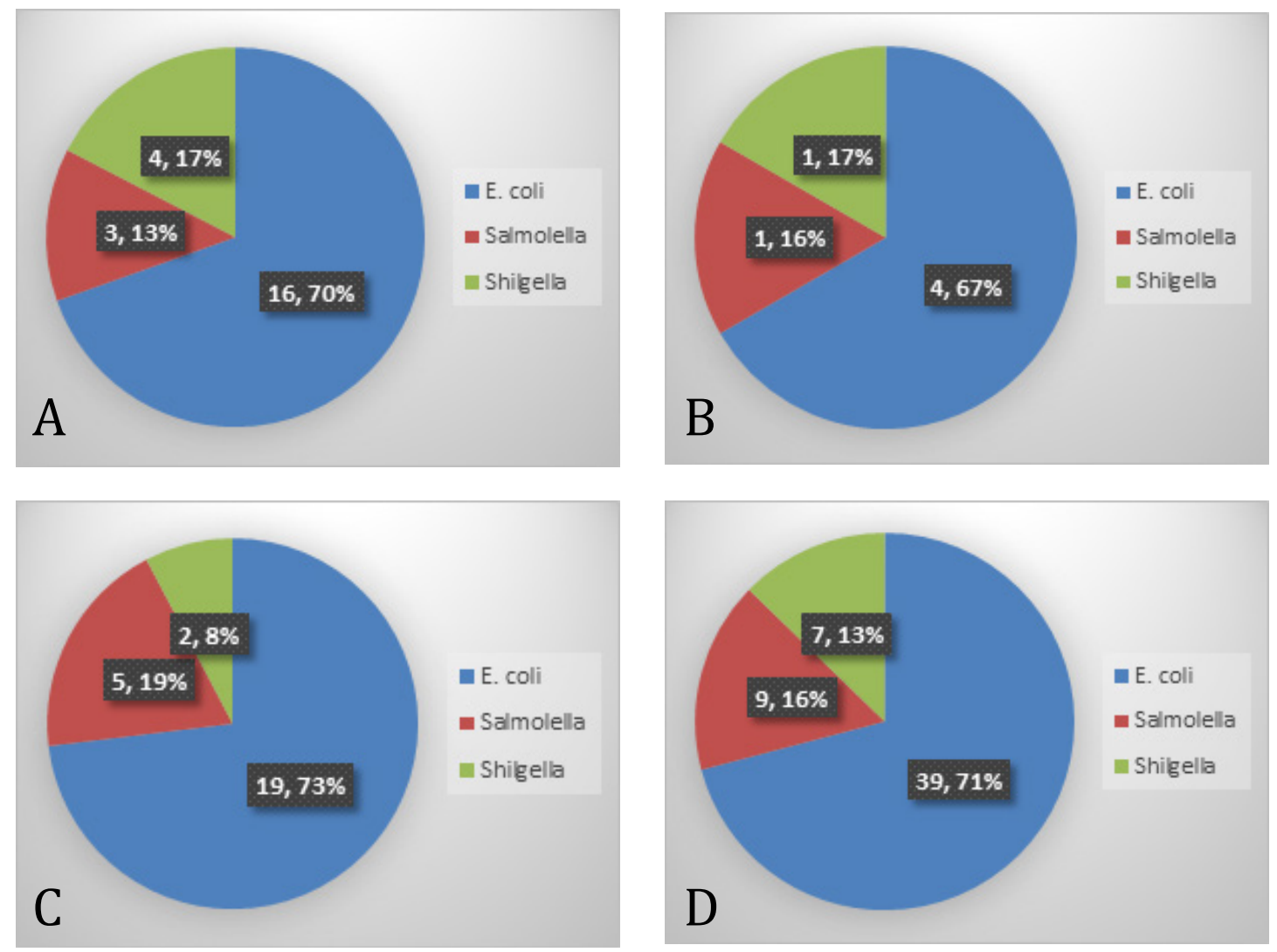

Figure 1. Distribution of the pathogens in diarrheal stools. A. distribution of pathogen in Up to years age, B. 5-9 years age, C. 10-15 years age, D. Total distribution of pathogen in child diarrheal stool

\section{DISCUSSION}

Given the importance of a careful characterization of the local epidemiology of diarrhea to guide specific antimicrobial therapy, we reviewed the results of 186 stool cultures from children aged 0 to 15 years old in which enteropathogens were detected. In this study, we found bacteria from more than a quarter of stool samples of children with acute gastroenteritis (29.57\%). Our findings are in agreement with the results of other studies from the developing countries reported between 16.8 to $33 \% .^{16-17}$ We detected a higher incidence during the first year of life to four years of age (the period when children's contact with environmental pathogens increases dramatically) and decreasing incidence levels in older children (5-9 years). In this study, the frequency of bacterial diarrhea in older age group (10-15 years) was significantly higher than the others that differ from the results of the other studies. ${ }^{18,19}$

E coli was the most common cause of bacterial diarrhea similar to many other previous studies. ${ }^{18,20-23}$ In our study, Salmonella (16.36\%) is the second most common cause of diarrhea and Shigella was found in $12.73 \%$ cases. In other studies, Shigella was more frequent. ${ }^{24-25}$ Indeed, most patients with shigellosis require immediate the hospitalization. ${ }^{26}$

In the present study, different bacterial species had different level of resistance pattern to different antibiotics. However, E. coli isolates were found to have a high rate of resistance to cotrimoxazole $(84.62 \%)$, cefotaxime (87.18\%) and cefixime (71.79\%). All in all, our susceptibility patterns are slightly more favorable than those reported by the large multicenter SENTRY Antimicrobial Surveillance Program Report for Brazil and Latin America. ${ }^{27}$

We found that the Salmonella strains were 
multi-susceptible, as high rates of resistance were not found against any of the drugs. We found no resistant to ciprofloxacin. But resistance to ciprofloxacin among non typhoidal Salmonella strains isolated from stool specimens has already been reported from several parts of the world. ${ }^{28,29}$ On the other hand, a multicenter Latin American study published by Gales et al. did not isolate any strain of Salmonella resistant to fluoroquinolones from blood samples. ${ }^{30}$ However, Salmonella spp. strains isolated from blood samples are recognized to be more susceptible than those from stools. ${ }^{31}$ Furthermore, the fluoroquinolone tested by Gales et al. was gatifloxacin, a new 8-methoxifluroquinolone that is supposed to be active against most ciprofloxacin-resistant bacteria.

Separate assessment of antimicrobial resistance patterns indicates that Shigella is more difficult to treat and requires careful consideration at the choice of antimicrobial therapy. However, Shigella resistance has not reached the alarming multi-resistance rates reported in other countries, where resistance to ciprofloxacin and to ceftriaxone is a reality. ${ }^{32-34}$ While we detected high resistance rates to amoxiclav, gentamicin and cefixime (71.43\%). And $71.43 \%$ were sensitive to ceftriaxone and ciprofloxacin. Prescription of antibiotics without laboratory guidance and over sales of antibiotics without proper drug prescription may be some of the different factors that can contribute to this high-level drug resistant pattern.

\section{CONCLUSION}

In conclusion, the results show that $E$. coli was the most frequently isolated pathogen in children. The majority of the bacterial isolates were resistant to multiple antibiotics. Hence, antibiotics susceptibility test is mandatory before prescribing any antibiotics. We recommend that antibiotics susceptibility test is mandatory before prescribing any antibiotics in children diarrhea.

\section{ACKNOWLEDGMENT}

We acknowledge the staff of Medical College Hospital Bacteriology laboratory staffs for their cooperation during data collection.

\section{COMPETING INTEREST}

The author declared that no competing interest with respect to the authorship and/or publication of this research paper

\section{REFERENCES}

1. Bern C, Martines J, de Zoysa I, Glass RI. The magnitude of the global problem of diarrhoeal disease: A ten-year update. Bulletin of the World Health Organization. 1992;70(6):705-14.

2. Guerrant RL, Hughes JM, Lima NL, Crane J. Diarrhea in developed and developing countries: Magnitude, special settings, and etiologies. Reviews of Infectious Diseases. 1990;12 Suppl 1:S41-50.

3. Gracey M. Diarrhea and malnutrition: A challenge for pediatricians. Journal of Pediatric Gastroenterology and Nutrition. 1996 Jan;22(1):6-16.

4. Ali MB, Ghenghesh KS, Aissa RB, Abuhelfaia A, Dufani M. Etiology of childhood diarrhea in Zliten, Libya. Saudi Medical Journal. 2005;26(11):1759-65.

5. Chatterjee BD, Thawani G, Sanyal SN. Etiology of acute childhood diarrhoea in Calcutta. Tropical Gastroenterology: Official Journal of the Digestive Diseases Foundation. 1989;10(3):158-66.

6. Diniz-Santos DR, Santana JS, Barretto JR, Andrade MGM, Silva LR. Epidemiological and microbiological aspects of acute bacterial diarrhea in children from Salvador, Bahia, Brazil. Brazilian Journal of Infectious Diseases. 2005;9(1):77-83.

7. Parashar UD, Gibson CJ, Bresee JS, Glass RI. Rotavirus and severe childhood diarrhea. Emerging Infectious Diseases. 2006;12(2):304-6.

8. Vernacchio L, Vezina RM, Mitchell AA, Lesko SM, Plaut AG, Acheson DW. Diarrhea in American infants and young children in the community setting: Incidence, clinical presentation and microbiology. The Pediatric Infectious Disease Journal. 2006;25(1):27. 
9. Gootz TD. The global problem of antibiotic resistance. Critical Reviews in Immunology. 2010;30(1):79-93.

10. Salyers A, Gupta A, Wang Y. Human intestinal bacteria as reservoirs for antibiotic resistance genes. Trends in Microbiology. 2004;12(9):412-6.

11. Blake DP, Hillman K, Fenlon DR, Low JC. Transfer of antibiotic resistance between commensal and pathogenic members of the Enterobacteriaceae under ileal conditions. Journal of Applied Microbiology. 2003;95(3):428-36.

12. Lester SC, Del Pilar PM, Wang F, Schael IP, Jiang $\mathrm{H}, \mathrm{O}^{\prime}$ Brien TF. The carriage of escherichia coli resistant to antimicrobial agents by healthy children in Boston, in Caracas, Venezuela, and in Qin $\mathrm{Pu}$, China. New England Journal of Medicine. 1990;323(5):285-9.

13. Nys S, Okeke IN, Kariuki S, Dinant GJ, Driessen C, Stobberingh EE. Antibiotic resistance of faecal Escherichia coli from healthy volunteers from eight developing countries. Journal of Antimicrobial Chemotherapy [Internet]. 2004;54(5):952-5. Available from: http://www.ncbi.nlm.nih. gov/pubmed/15471998

14. Murray B, Pfaller T. In manual of clinical microbiology. 6th ed. Washington DC: American Society of Microbiology Press; 1999.

15. Clinical and Laboratory Standards Institute. Performance standards for antimicrobial susceptibility testing; seventeeth information supplement. CLSI document M100 S17. Pennsylvania; 2006.

16. Bauer AW, Kirby WM, Sherris JC, Turck M. Antibiotic susceptibility testing by a standardized single disk method. American Journal of Clinical Pathology. 1966;45(4):493-6.

17. Al Jarousha AM, El Jarou MA, El Qouqa IA. Bacterial enteropathogens and risk factors associated with childhood diarrhea. The Indian Journal of Pediatrics. 2011;78(2):165-70.

18. Kansakar P, Baral P, Malla S, Ghimire GR. Antimicrobial susceptibilities of enteric bacterial pathogens isolated in Kathman$\mathrm{du}$, Nepal, during 2002-2004. Journal of In- fection in Developing Countries. 2011 Mar 21;5(3):163-8.

19. Moyo SJ, Gro N, Matee MI, Kitundu J, Myrmel $\mathrm{H}$, Mylvaganam $\mathrm{H}$, et al. Age specific aetiological agents of diarrhoea in hospitalized children aged less than five years in Dar es Salaam, Tanzania. BioMed Central Pediatrics [Internet]. 2011;11(1):19. Available from: http://www.ncbi.nlm.nih.gov/ pubmed/21345186

20. Nimri LF, Elnasser Z, Batchoun R. Polymicrobial infections in children with diarrhoea in a rural area of Jordan. FEMS Immunology \& Medical Microbiology. 2004;42(2):255-9.

21. Nair GB, Ramamurthy T, Bhattacharya MK, Krishnan T, Ganguly S, Saha DR, et al. Emerging trends in the etiology of enteric pathogens as evidenced from an active surveillance of hospitalized diarrhoeal patients in Kolkata, India. Gut pathogens. 2010;2(1):4.

22. Guerrant RL, Hughes JM, Lima NL, Crane J. Diarrhea in developed and developing countries: Magnitude, special settings, and etiologies. Reviews of Infectious Diseases. 1990;12:S41-50.

23. Nweze EI. Aetiology of diarrhoea and virulence properties of diarrhoeagenic escherichia coli among patients and healthy subjects in southeast Nigeria. Journal of Health, Population, and Nutrition. 2010;28(3):245-52.

24. Garcia PG, Silva VL, Diniz CG. Occurrence and antimicrobial drug susceptibility patterns of commensal and diarrheagenic escherichia coli in fecal microbiota from children with and without acute diarrhea. The Journal of Microbiology. 2011;49(1):46-52.

25. Kansakar P, Baral P, Malla S, Ghimire GR. Antimicrobial susceptibilities of enteric bacterial pathogens isolated in Kathmandu, Nepal, during 2002-2004. Journal of Infection in Developing Countries. 2011;21(5):163-8.

26. Mota MI, Gadea MP, González S, González G, Pardo L, Sirok A, et al. Bacterial pathogens associated with bloody diarrhea in 
Uruguayan children. Revista Argentina de Microbiologia. 42(2):114-7.

27. Niemogha MT, Alabe SA, Uzoma KL, et al. The incidence of Salmonella, Shigella and other enteric bacterial pathogens in stool specimens of diarrhea patients. Nigerian Medical Journal. 1998;28:70-4.

28. Sader HS, Jones RN, Gales AC, Silva JB, Pignatari AC. SENTRY antimicrobial surveillance program report: latin american and brazilian results for 1997 through 2001. Brazilian Journal of Infectious Diseases. 2004;8(1):25-79.

29. Jiang Zhi-Dong, Lowe B, Verenkar MP, Ashley D, Steffen R, Tornieporth N, et al. Prevalence of enteric pathogens among international travelers with diarrhea acquired in Kenya (Mombasa), India (Goa), or Jamaica (Montego Bay). The Journal of Infectious Diseases. 2002;185(4):497-502.

30. Taneja N, Mohan B, Khurana S, Sharma M. Antimicrobial resistance in selected bacterial enteropathogens in north India. The Indian Journal of Medical Research. 2004;120(1):39-43.

31. Gales AC, Sader HS, Mendes RE, Jones RN. Salmonella spp. isolates causing bloodstream infections in Latin America: report of antimicrobial activity from the SENTRY Antimicrobial Surveillance Program (1997-2000). Diagnostic Microbiology and Infectious Disease. 2002;44(3):313-8.

32. Oplustil CP, Nunes R, Mendes C. Multicenter evaluation of resistance patterns of klebsiella pneumoniae, escherichia coli, salmonella spp and shigella spp isolated from clinical specimens in Brazil: RESISTNET surveillance program. Brazilian Journal of Infectious Diseases. 2001;5(1):8-12.

33. Niyogi SK, Mitra U, Dutta P. Changing pattern of serotypes and antimicrobial susceptibility of Shigella species isolated from children in Calcutta, India. Japanese Journal of Infectious Diseases. 2001;54:121-2.

34. Sur D, Niyogi SK, Sur S, Datta KK, Takeda Y, Nair GB, et al. Multidrug-resistant Shigella dysenteriae type 1: Forerunners of a new epidemic strain in eastern India? Emerging Infectious Diseases. 2003;9(3):404-5.
35. Gassama A, Sow PS, Fall F, Camara P, GuèyeN'diaye A, Seng R, et al. Ordinary and opportunistic enteropathogens associated with diarrhea in Senegalese adults in relation to human immunodeficiency virus serostatus. International Journal of Infectious Diseases: IJID : Official Publication of the International Society for Infectious Diseases. 2001;5(4):192-8. 